\title{
Evaluation of Kidney Functions After Nephrectomy: Single Center Experience
}

\author{
Nefrektomi Sonrası Böbrek Fonksiyonunun \\ Değerlendirilmesi: Tek Merkez Deneyimi
}

\author{
Hazen Saritas ${ }^{1}$, Fesih $\mathrm{Ok}^{2}$, Omer Erdogan²
}

${ }^{1}$ Aksaray University, Faculty of Medicine Training and Research Hospital Department of Nephrology, Aksaray, Turkey

${ }^{2}$ Siirt State Hospital, Department of Urology Siirt, Turkey

Address correspondence to: Hazen Saritas, Aksaray University, Faculty of Medicine Training and Research Hospital Department of Nephrology, Aksaray, Turkey e-mail: hazensaritas@hotmail.com

Geliş Tarihi/Received: 21 April 2021 Kabul Tarihi/Accepted: 28 July 2021

\begin{abstract}
Öz
Amaç: Bu çalışmada tek böbreği kalan bireylerde böbrek fonksiyonu, hipertansiyon gelişimi ve proteinüriyi araştırmak amaçlanmıştır.

Hastalar ve Yöntem: Çalışmaya Ocak 2016-Aralık 2019 tarihleri arasında çeşitli nedenlerle Siirt Devlet Hastanesi Nefroloji ve Üroloji polikliniklerine başvuran 17800 hasta arasından daha önce nefrolitiyazis ve kronik piyelonefrite bağlı nonfonksiyone böbrek, RCC (Renal Cell Karsinom), travma ve donör nefrektomi nedeniyle nefrektomi yapılmış 96 hasta dahil edildi. Hastaların verileri retrospektif olarak hasta dosyalarından elde edildi.

Bulgular: Çalışmaya 45 'i kadın 51 'i erkek olmak üzere toplam 96 hasta dahil edildi. Hastaların 23'üne (\% 24) donör nefrektomi (DN) yapılmış, 73'üne (\%76) nefrolitiyazis, kronik piyelonefrit, travma ve Renal Cell Hücreli Kanser (RCC) nedeniyle nefrektomi yapılmıştı. Hastalar DN yapılanlar ve diğer etyolojiler nedeniyle nefrektomi (DE) yapılan hastalar olarak iki gruba ayrıldı. DN grubu ile DE grubu arasında sırasıyla; yaş ortalamaları, kadın erkek dağııımı, nefrektomi öncesi HT varlığı, DM, hematüri ve yeni başlangıçlı proteinüri varlığı yönünden karşılaştırıldığında istatistiksel olarak anlamlı farklılık görülmedi $(P>0.05)$. DN grubuna göre DE grubunda yeni başlangıçlı KBH ve HT gelişme sıklığı istatistiksel anlamlı olarak daha yüksek idi $(P<0.05)$.

Sonuç: Nefrektomi KBH, proteinüri ve HT gelişimi için risk faktörüdür. Bu nedenle benign hastalıklar nedeniyle yapılan nefrektomilerin prevalansını azaltmak için zamanında önleyici tedbirler alınmalıdır.

Anahtar Kelimeler: Kronik böbrek hastalığı, proteinüri, nefrektomi

Abstract

Aim: In this study, it was aimed to investigate the kidney function, hypertension development and proteinuria in individuals with only one kidney.

Patients and Methods: The study included 96 patients who had previously undergone nephrectomy with the causes of nephrolithiasis and chronic pyelonephritis-induced nonfunctional kidney, RCC (Renal Cell carcinoma), trauma, and donor nephrectomy among 17800 patients who applied to the Siirt State Hospital Nephrology and Urology outpatient clinics between January 2016 and December 2019. The data of the patients were obtained from patient files database retrospectively.

Results: A total of 96 patients, 45 female and 51 male, were included in the study. $23(24 \%)$ of the patients had donor nephrectomy (DN), and $73(76 \%)$ had nephrectomy (DE) due to nephrolithiasis, chronic pyelonephritis, trauma, and renal cell cancer (RCC). The patients were divided into two groups as those who underwent DN and DE due to other etiologies. Between DN and DE group, there was no statistically significant difference in terms of mean age, distribution of gender, presence of HT before nephrectomy, $D M$, presence of hematuria and new onset proteinuria $(P>0.05)$. Compared to the $D N$ group, the frequency of new onset in CKD and HT development was significantly higher DE group.

Conclusion: Nephrectomy is a risk factor for the development of CKD, proteinuria and hypertension. Therefore, preventive measures should be taken in a timely manner to reduce the prevalence of nephrectomies due to benign diseases.
\end{abstract}

Key words: Chronic kidney disease, proteinuria, nephrectomy
Cite this article as: Saritas H, Ok F, Erdogan O. Evaluation of Kidney Functions After Nephrectomy: Single Center Experience. Selcuk Med J 2021;37(3): 218-223

"This article is licensed under a Creative Commons Attribution-NonCommercial 4.0 International License (CC BY-NC 4.0)"
Disclosure: None of the authors has a financial interest in any of the products, devices, or drugs mentioned in this article. The research was not sponsored by an outside organization. All authors have agreed to allow full access to the primary data and to allow the journal to review the data if requested. 


\section{INTRODUCTION}

Chronic kidney disease (CKD) is a health problem that is increasing worldwide and poses a significant burden on the economy of countries (1). In addition, CKD is found to be a strong risk factor for cardiovascular mortality(2). The solitary kidney is mostly caused by; unilateral kidney agenesis; congenital hypoplasia and dysplasia, and surgical removal of the kidney due to disease, injury, tumor or kidney donation. Decreased nephron count with nephrectomy causes hypertension, proteinuria, and a decrease in long-term glomerular filtration rate (GFR) (3). CKD may develop in people with solitary kidneys and in addition to its extraordinary healthcare costs it can lead to end-stage kidney disease (ESRD). In the past, nephrectomy for live kidney donation has been considered safe without the possibility of developing CKD, while new data suggest that there is an 8-11 times greater relative risk of ESRD after unilateral nephrectomy (3-7). Nephrectomy increases the risk of cardiovascular events and death by causing $\operatorname{CKD}(8$, 9).

Decreased kidney capacity in individuals with nephrectomy may contribute to metabolic acidosis (MA) by leading to endogenous and dietary kidney acid burden(10). Pathogenesis of CKD and ESRD in kidney donors with solitary kidney may differ from those of CKD without nephrectomy. Physiological adaptation in the solitary kidney causes higher glomerular filtration rates (GFR) compared to the nephron units. It initially increases GFR but may lead to a gradual decrease in kidney function in the long term (11). Kidney stones and kidney stonerelated CKD are common and affect 5 and $13 \%$ of the adult population, respectively (12). Although clinical outcomes such as renal failure, development of hypertension, coronary artery disease in patients with solitary kidney have been extensively investigated in previous studies, clinical problems caused by a solitary kidney are still controversial $(1,3,9,13)$. There are a lot of evidences suggesting that a congenital or acquired reduction in kidney mass predisposes the patient to HT, proteinuria, and, in the long term, a decrease in the GFR rate $(3,14,15)$. The aim of this study is to investigate the development of CKD, proteinuria and hypertension in the post-nephrectomy follow-up of individuals who have had a single kidney after donor nephrectomy or other reasons.

\section{PATIENTS AND METHODS}

The study included 96 patients who had undergone nephrolithiasis and chronic pyelonephritis-induced nonfunctional kidney, RCC, trauma, and donor nephrectomy among the 17800 patients who applied to the Siirt State Hospital Nephrology and Urology outpatient clinics between January 2016 and December 2019. The data of the patients were obtained from patient files retrospectively. Ethical approval for this study was obtained from the NonInterventional Clinical Research Ethics Committee. (Decision number 31.12.2020, 2020 / 13.11). The study was carried out in accordance with the Helsinki Declaration.

\section{Statistical analysis}

The Kolmogorov-Smirnov test was used to investigate whether the distribution of continuous numerical variables is distributed close to normal or not, and the assumption of homogeneity was verified with the Levene test. Descriptive statistics: While mean \pm standard deviation or median (25th - 75th) percentages were used for continuous numerical variables, categorical variables were shown as number of cases and (\%) percentages. Student's $t$ test was used to determine the significance of the difference in terms of continuous numerical variables in which parametric test statistic assumptions are provided between the groups, while Mann Whitney $U$ test was used to determine the significance of the difference in terms of continuous numerical variables in which sortable variables and parametric test statistic assumptions were not provided. Categorical variables were analyzed by continuity corrected ChiSquare or Fisher's exact probability test.

Analysis of the data was done in IBM SPSS Statistics 17.0 (IBM Corporation, Armonk, NY, USA) package program. Results with $p<0.05$ were considered statistically significant.

\section{RESULTS}

A total of 96 patients with normal GFR values, 45 female and 51 male, were included in the study. $23(24 \%)$ of the patients had donor nephrectomy, $73(76 \%)$ had nephrectomy due to nephrolithiasis, chronic pyelonephritis, trauma and Renal Cell Cancer (RCC). There were 7 patients in total who underwent nephrectomy for RCC. 3 of the patients were stage $2 a$ and 4 of them were stage $2 b$. The patients were divided into two groups as those who underwent donor nephrectomy (DN) and those who underwent nephrectomy (DE) due to other etiologies. Creatinine, uric acid, $\mathrm{PTH}, \mathrm{pH}$, Chronic Kidney Disease Epidemiology Collaborative equation (CKD- 
Table 1. Frequency distributions of cases according to nephrectomy cause

\begin{tabular}{lll}
\hline Nephrectomy cause & Number of cases & Percentage \\
\hline Nephrolithiasis & 57 & 59.4 \\
Donor nephrectomy & 23 & 24.0 \\
Renal cell carcinoma & 7 & 7.3 \\
Chronic pyelonephritis & 8 & 8.3 \\
Trauma & 1 & 1.0 \\
Total & 96 & 100.0 \\
\hline
\end{tabular}

EPI) GFR, complete urine test, protein and creatinin spot urinalysis and vitamin D levels examined in both groups. Proteinuria was accepted in patients with Protein / Creatinine $>150 \mathrm{mg} / \mathrm{g}$ in spot urine. CKD was defined as the presence of predicted GFR $<60$ $\mathrm{ml} / \mathrm{min} / 1.73 \mathrm{~m}^{2}$ and / or proteinuria in two or more biochemical and spot urinalysis of the patient. The estimated glomerular filtration rate (eGFR) CKD-EPI equation. Urinary system ultrasonographies performed before in outpatient follow-ups for nephrectomy were examined. Table 1 shows the frequency distributions of the cases according to the causes of nephrectomy. Table 2 shows the comparisons made in terms of demographic and clinical features of the cases according to the causes of nephrectomy.

Between DN group and DE group, respectively; there was no statistically significant difference in terms of mean age, distribution of gender, presence of HT before nephrectomy, history of DM, presence of hematuria and proteinuria ( $p>0.05)$. However, the time elapsed after nephrectomy in the DE group was statistically significantly shorter than the DN group ( $P$
$<0.001)$. For both group's patients with GFR below $60 \mathrm{ml} / \mathrm{min} / 1.73 \mathrm{~m}^{2}$ according to CKD-EPI were considered as developing new CKD. In the DE group, the development of new CKD was detected in $54.8 \%$ patients and in the DN group, 39\% of the patients. Compared to the DN group (median CKD stage: 2, min: 1 - max: 3b), CKD stage was also statistically significantly higher in the DE group (median CKD stage: 3a, min: 1 - max: 5) $(P=0.030)$. In $D E$ group, $67 \%$ of men and $45 \%$ of women developed CKD. In Table 3, comparisons made in terms of biochemical measurements of the cases according to the causes of nephrectomy were given.

Between DN group and DE group, respectively; there was no statistically significant difference in terms of $\mathrm{Na}+, \mathrm{K}+$, uric acid, $\mathrm{PTH}, \mathrm{pH}$, proteinuria and CKD-EPI GFR levels ( $p>0.05$ ). However, compared to the DN group, urea, creatinine, phosphorus and vitamin $D$ levels were statistically higher in the $D E$ group ( $p<0.05$ ). Also, compared to the DN group, calcium, albumin, HCO3- and hemoglobin levels were statistically lower in the DE group $(p<0.05)$.

Table 2. Demographic and clinical features of cases according to nephrectomy cause

\begin{tabular}{|c|c|c|c|}
\hline & $\begin{array}{c}\text { Donor nephrectomy (DN) } \\
(n=23)\end{array}$ & $\begin{array}{c}\text { Other etiologies (DE) } \\
(n=73)\end{array}$ & P-value \\
\hline$\overline{\text { Age }}$ & $48.9 \pm 15.1$ & $50.2 \pm 18.6$ & $0.762 \dagger$ \\
\hline Sex & & & $0.068 \ddagger$ \\
\hline Male & $9(39.2 \%)$ & $42(57.5 \%)$ & \\
\hline Female & $14(60.8 \%)$ & $31(42.5 \%)$ & \\
\hline HT before nephrectomy & $1(5.0 \%)$ & $7(12.3 \%)$ & $0.672 \$$ \\
\hline Time after nephrectomy (Year) & $1.0(1.0-12.0)$ & $10.0(1.0-40.0)$ & $<0.001 \rrbracket$ \\
\hline \multicolumn{4}{|l|}{ After nephrectomy } \\
\hline HT & $8(40.0 \%)$ & $36(63.2 \%)$ & $0.124 \ddagger$ \\
\hline DM & $1(5.0 \%)$ & $9(15.8 \%)$ & $0.439 \$$ \\
\hline HD & $0(0.0 \%)$ & $9(12.3 \%)$ & $0.077 \$$ \\
\hline Proteinuria & $3(13.0 \%)$ & $24(32.9 \%)$ & $0.065 \ddagger$ \\
\hline \multicolumn{4}{|l|}{ CKD stage } \\
\hline 1 & $2(10.0 \%)$ & $6(10.5 \%)$ & \\
\hline 2 & $10(50.0 \%)$ & $17(29.8 \%)$ & \\
\hline $3 a$ & $7(35.0 \%)$ & $15(26.3 \%)$ & \\
\hline $3 b$ & $1(5.0 \%)$ & $7(12.3 \%)$ & \\
\hline 4 & $0(0.0 \%)$ & $10(17.5 \%)$ & \\
\hline 5 & $0(0.0 \%)$ & $2(3.5 \%)$ & \\
\hline
\end{tabular}


Table 3. Biochemical measurements of cases according to nephrectomy cause

\begin{tabular}{|c|c|c|c|}
\hline & $\begin{array}{c}\text { Donor nephrectomy (DN) } \\
(n=23)\end{array}$ & $\begin{array}{l}\text { Other etiologies(DE) } \\
(n=73)\end{array}$ & P-value \\
\hline$\overline{\text { Creatinine (mg/dl) }}$ & $1.1(1.0-1.3)$ & $1.3(1.1-1.8)$ & $0.004 \dagger$ \\
\hline $\mathrm{Ca}++(\mathrm{mg} / \mathrm{dl})$ & $9.42 \pm 0.28$ & $9.19 \pm 0.47$ & $0.011 \ddagger$ \\
\hline Phosphorus (mg/dl) & $3.3(2.9-3.7)$ & $3.6(3.2-4.1)$ & $0.007 \dagger$ \\
\hline Albumin $(\mathrm{g} / \mathrm{L})$ & $4.3(4.2-4.5)$ & $4.2(4.0-4.3)$ & $0.018 \dagger$ \\
\hline Uric acid (mg/dl) & $5.9(4.6-6.5)$ & $6.6(5.5-7.5)$ & $0.016 \dagger$ \\
\hline PTH $(\mathrm{pg} / \mathrm{mL})$ & $94.0(77.2-27.2)$ & $84.0(55.0-131.5)$ & $0.601 \dagger$ \\
\hline Vitamin D (IU) & $7.4(5.0-13.8)$ & $17.9(10.9-5.5)$ & $<0.001 \dagger$ \\
\hline $\mathrm{pH}$ & $7.38(7.37-7.38)$ & $7.37(7.36-7.38)$ & $0.051 \dagger$ \\
\hline $\mathrm{HCO} 3-$ & $25.7 \pm 0.8$ & $24.9 \pm 1.8$ & $0.016 \ddagger$ \\
\hline Proteinuria (mg/gr) & $80.0(62.0-20.0)$ & $96.0(56.0-350.0)$ & $0.257 \dagger$ \\
\hline CKD-EPI GFR $\left(\mathrm{ml} / \mathrm{min} / \mathrm{per} / 1.73 \mathrm{~m}^{2}\right)$ & $67.0 \pm 18.0$ & $54.6 \pm 26.7$ & $0.024 \ddagger$ \\
\hline Hemoglobin (g/dl) & $13.9 \pm 1.3$ & $13.1 \pm 1.7$ & $0.063 \ddagger$ \\
\hline
\end{tabular}

† Mann-Whitney U test, ¥ Student’s t-test, Ca++: calcium, PTH: parathyroid hormone HCO3-: bicarbonate, CKD-EPI: chronic kidney disease epidemiology, GFR: glomerular filtration rate

\section{DISCUSSION}

Recent advances in the early diagnosis and treatment of kidney disease have significantly reduced the number of nephrectomies, especially for benign kidney diseases(16). Clinically important renal endpoints after nephrectomy include development of CKD, proteinuria, and ESRD (17). In recent studies, the risk of ESRD after DN has been shown to increase relatively 3-5 times $(1,4-6)$. There is an increasing acceptance that CKD is found to be a strong risk factor for cardiovascular mortality(2). In addition, other important complications of CKD include HT, anemia, malnutrition, neuropathy, poor quality of life, and mortality risk $(18,19)$. In the literature, there are geographical differences in terms of nephrectomy rates according to etiology. Nephrectomy rates due to malignant diseases were $67.7 \%$ in Norvay (20) and $68 \%$ in Nigeria (21), whereas nephrectomy rates due to benign diseases were $76.6 \%$ in Pakistan (22) and 70\% in Jordan (23). In our study, the rate of nephrectomy due to benign diseases was $68.7 \%$. More than half of the group $(78 \%)$ had stones in etiology similar to the study made in Pakistan (22). In our study, the high rate of simple nephrectomy due to stone disease may be related to warm climatic conditions, feeding habits, hydro mineralogy and dehydration (24). Advances in the early diagnosis, minimally invasive treatment, and adequate prophylactic measures in urinary stone disease have led to a decrease in the incidence of nephrectomies (12).

In previous studies, it was emphasized that the relationship between male gender and CKD development is stronger among patients with solitary kidneys $(3,5)$. Similarly, in our study, $67 \%$ of males and $45 \%$ of females developed CKD in the DE group. However, it does not seem to be possible to explain the relationship between male gender and CKD development with our study. More comprehensive studies are needed to explain this relationship. Compensatory glomerular hyperfiltration due to a reduction in kidney mass can damage the solitary kidney in the long term, especially if there are other factors that exacerbate glomerular hyperfiltration, such as high protein and salt intake with $\operatorname{diet}(1,25)$. The reduction in kidney mass leads to progressive glomerular damage associated with glomerular hypertrophy, hyperfiltration, and systemic hypertension(3). HT development in the follow-up of solitary kidney patients was reported as $28 \%$ in the study of Imen Abdellaoui et al.(26), 36\% in the study of A.J. Haugen et al. (27) and $50.6 \%$ in the study of J.A. Campos-Sanudo et al.(28). In our study, in the long-term follow-up in the postoperative period, HT developed in $43.5 \%$ of patients in the DN group and in $46.5 \%$ in the DE group.

A population-based analysis suggested that proteinuria is a risk factor independent of the glomerular filtration rate for the development of ESRD or cardiovascular disease(29). It has been previously shown that a reduction in nephron mass causes an increase in proteinuria in animal models (30). In studies in solitary kidney patients, proteinuria development rates were reported as $12.5 \%(26)$ and $25 \%(31)$. In our study, similarly the proteinuria was observed in $24 \%$ of patients in the DE group in postoperative period. Whereas proteinuria was detected in 3\% of the patients in the DN group. The lower rate of proteinuria in the DN group may be related to the selection of healthy individuals for donor nephrectomy. In our study, the CKD stage was also significantly higher in 
the DE group (median CKD stage: 3a, min: 1 - max: 5) compared to the DN group (median CKD stage: 3a, min: 1 - max: 5) $(P<0.05)$. This situation was thought to be related to the selection of candidates for DN from the normal and healthy adults. Zhang et al. (9) reported that new-onset CKD developed in $52.9 \%$ of patients who underwent unilateral nephrectomy. Eymen G. et al.(32) reported the rate of CKD development as $25.7 \%$ in the donor nephrectomy group and $50.8 \%$ in the radical nephrectomy group. In our study, new onset CKD was found in $54.8 \%$ of patients in the DE group which supports the previous studies. In our study, the development rate of new-onset CKD in the DN group was $39 \%$. This rate is lower than that of the $\mathrm{DE}$ group and the absence of stage 4-5 KBH may be associated with more preserved kidney function in individuals with $\mathrm{DN}$.

CKD can lead to metabolic acidosis as a result of inadequate renal tubular bicarbonate reabsorption or abnormal bicarbonate production (33). In previous studies, metabolic acidosis and CKD have been observed with a higher rate in patients undergoing radical nephrectomy $(34,35)$. In our study, compared to the DN group, urea, creatinine, phosphorus, and vitamin $D$ levels were statistically higher in the $D E$ group ( $p<0.05$ ). Also, according to the DN group, in the DE group, respectively; Calcium, albumin, HCO3and hemoglobin levels were statistically lower ( $p$ $<0.05$ ). These results can be explained by the higher rate of CKD development in the DE group compared to the DN group, and that the CKD stage was more advanced. One of the important factors affecting the results of nephrectomy is the time elapsed after nephrectomy. Renal parenchymal loss is a risk factor for worsening kidney function over time. The time elapsed after nephrectomy is inversely related to GFR(9). In our study, it was observed that the loss of GFR increased with the prolongation of the time after nephrectomy. The limitations of our study are that it was a single-center and retrospective study, the number of patients was low, the follow-up period was short in the DN group, and the subgroup analysis was not performed due to the small number of patients in the DE group.

Nephrectomy is a risk factor for the development of CKD, proteinuria and hypertension. Therefore, preventive measures should be selected in a timely manner to reduce the prevalence of nephrectomies due to benign diseases. Patients need systematic nephrological care after nephrectomy to prevent the progression of CKD. More research is needed to better understand the risk of CKD after nephrectomy and to optimize patient management. Nephronsparing surgery should be preferred if possible in patients who will undergo nephrectomy for RCC.

Conflict of interest: Authors declare that there is no conflict of interest between the authors of the article.

Financial conflict of interest: Authors declare that they did not receive any financial support in this study.

Address correspondence to: Hazen Saritas, Aksaray University, Faculty of Medicine Training and Research Hospital, Department of Nephrology, Aksaray, Turkey e-mail: hazensaritas@hotmail.com

GSM: +905336095661

\section{REFERENCES}

1. Tantisattamo E, Dafoe DC, Reddy UG, et al. Current management of acquired solitary kidney. Kidney Int Rep 2019;4(9):1205-18.

2. Lopau $\mathrm{K}$, Wanner $\mathrm{C}$. Treatment rationale for coronary heart disease in advanced CKD Herz 2021:1-6.

3. Mjøen G, Hallan S, Hartmann A, et al. Long-term risks for kidney donors. Kidney Int 2014;86(1):162-7.

4. Muzaale AD, Massie AB, Wang M-C, et al. Risk of end-stage renal disease following live kidney donation. J Am Med Assoc 2014;311(6):579-86.

5. Grams ME, Sang Y, Levey AS, et al. Kidney-failure risk projection for the living kidney-donor candidate. $\mathrm{N}$ Engl J Med 2016;374(5):411-21.

6. Kim S, Chang Y, Lee YR, et al. Solitary kidney and risk of chronic kidney disease. Eur j Epidemiol 2019;34(9):879-88.

7. Massie $A B$, Holscher $C M$, Henderson ML, et al. Association of early postdonation renal function with subsequent risk of end-stage renal disease in living kidney donors. J Am Med Assoc Surg 2020;155(3):e195472-e.

8. Ellis RJ. Chronic kidney disease after nephrectomy: A clinically-significant entity? Transl Androl Urol 2019;8(Suppl 2):S166.

9. Zhang WJ, Wang ZY, Zhou WX, et al. Identifying risk factors for chronic kidney disease stage 3 in adults with acquired solitary kidney from unilateral nephrectomy: A retrospective cohort study. BMC Nephrol 2020;21(1):1-10.

10. Madias NE. Metabolic acidosis and CKD progression.Clin J Am Soc Nephrol 2021;16(2):310-2.

11. Matas AJ, Vock DM, Ibrahim HN. GFR $\leq 25$ years postdonation in living kidney donors with (vs. without) a first-degree relative with ESRD Am J Transplant 2018;18(3):625-31.

12. Raheem OA, Khandwala $\mathrm{YS}$, Sur RL, et al. Burden of urolithiasis: Trends in prevalence, treatments, and costs. Eur Urol Focus 2017;3(1):18-26.

13. Fournier $\mathrm{C}$, Pallet $\mathrm{N}$, Cherqaoui $Z$, al. Very long-term followup of living kidney donors. Transpl Int 2012;25(4):385-90.

14. Saxena AB, Myers BD, Derby G, et al. Adaptive hyperfiltration in the aging kidney after contralateral nephrectomy. Am J Physiol Renal Physiol 2006;291(3):F629-34.

15. Brenner BM, MacKenzie HS. Nephron mass as a risk factor for progression of renal disease. Kidney Int Suppl 1997;63:S124-7. 
16. Hagos M. Indications and outcomes of nephrectomy in ayder comprehensive specialized and mekelle hospitals, northern ethiopia: A 5 year experience. Ethiop Med J 2019;57(1):13-8.

17. Lentine KL, Lam NN, Segev DL. Risks of living kidney donation: Current state of knowledge on outcomes important to donors. Clin J Am Soc Nephrol 2019;14(4):597-608.

18. Chen TK, Knicely DH, Grams ME. Chronic kidney disease diagnosis and management: A review. J Am Med Assoc 2019;322(13):1294-304.

19. Forbes A, Gallagher H. Chronic kidney disease in adults: Assessment and management. Clin Med 2020;20(2):128.

20. Beisland C, Medby PC, Sander S, et al. Nephrectomyindications, complications and postoperative mortality in 646 consecutive patients. Eur Urol 2000;37(1):58-64.

21. Eke N, Echem R. Nephrectomy at the University of Port Harcourt Teaching Hospital: A ten-year experience. Afr J Med 2003;32(2):173-7.

22. Rafique M. Nephrectomy: Indications, complications and mortality in 154 consecutive patients. J Pak Med Assoc 2007;57(6):308-11.

23. Ghalayini IF. Pathological spectrum of nephrectomies in a general hospital. Asian J Surg 2002;25(2):163-9.

24. Sofia NH, Walter TM, Sanatorium T. Prevalence and risk factors of kidney stone. Glob J Res Anal 2016;5(3):183-7.

25. Ko GJ, Obi Y, Tortoricci AR, et al. Dietary protein intake and chronic kidney disease. Curr Opin Clin Nutr Metab Care 2017;20(1):77.

26. Abdellaoui I, Azzabi A, Sahtout W, et al. Short-and long-term follow-up of living kidney donors. Saudi J Kidney Dis Transpl 2019;30(2):401.
27. Haugen AJ, Hallan S, Langberg NE, et al. Increased longterm risk for hypertension in kidney donors-a retrospective cohort study. Transpl Int 2020;33(5):536-43.

28. Campos Sañudo J, Ballestero Diego R, Zubillaga Guerrero $S$, et.al. Impact of radical nephrectomy on kidney function and prognostic factors for adverse cardiovascular events. Actas Urol Esp (English Edition) 2020;44(4):239-44.

29. Arai R, Suzuki S, Kano H, et al. Role of dipstick proteinuria for predicting cardiovascular events: A Japanese cardiovascular hospital database analysis. Heart Vessels 2020;35(9):125669.

30. Hostetter TH, Olson J, Rennke H, et el. Hyperfiltration in remnant nephrons: A potentially adverse response to renal ablation. J Am Soc Nephrol 2001;12(6):1315-25.

31. Catalina SB, Katherine PNA, Nicolas F, et al. The natural history of solitary post-nephrectomy kidney in a pediatric population. International Braz J Urol 2019;45(6):1227-37.

32. Gazel E, Biçer S, Ölçücüoğlu EA, et al. Comparison of renal function after donor and radical nephrectomy. Ren Fail 2015;37(3):377-80.

33. Kraut JA, Kurtz I. Metabolic acidosis of CKD: Diagnosis, clinical characteristics, and treatment. Am J Kidney Dis 2005;45(6):978-93.

34. Etafy M, Saleh F, Aal MA, et al. Comparison of renal function following donor nephrectomy versus radical nephrectomy for renal tumor. Saudi J Kidney Dis Transpl 2015;26(2):238.

35. Malcolm JB, Bagrodia A, Derweesh IH, et al. Comparison of rates and risk factors for developing chronic renal insufficiency, proteinuria and metabolic acidosis after radical or partial nephrectomy. BJU Int 2009;104(4):476-81. 